\title{
BADANIA SONDAŻOWE OPINII KONSUMENTÓW WODY Z WODOCIĄGU MIELECKIEGO
}

\begin{abstract}
Badania sondażowe są ważnym elementem pozwalającym poprawić działanie systemu zaopatrzenie $\mathrm{w}$ wodę oraz bezpieczeństwo jego funkcjonowania. W pracy przedstawiono wyniki badań przeprowadzonego sondażu, na temat zadowolenia z funkcjonowania wodociągów publicznych przez konsumentów korzystających $\mathrm{z}$ ich usług. W badaniu udział wzięło 100 respondentów z miasta Mielec. Badanie obejmowało opinie ankietowanych na temat cen i jakości wody, nieudogodnień oraz poziomu uciążliwości jaki są związane z przerwami w dostawie wody.
\end{abstract}

Słowa kluczowe: ankieta, system zaopatrzenia w wodę, przerwy w dostawie wody

\section{Wstęp}

Badania marketingowe mają za zadnie między innymi sprawdzić jakie odczucia budzą $\mathrm{w}$ konsumentach określone produkty oraz na jakie nowe produkty jest zapotrzebowanie $[1,2]$. W każdej dziedzinie życia pojawiają się badania sondażowe. Badanie opinii konsumentów wody ma za zadanie poznanie odczuć ludzi, związanych ze spożywaną przez nich wodą oraz wzajemnych relacji $\mathrm{z}$ firmą wodociągową [5-8, 10-12].

Badania możemy przeprowadzić na informacjach, które już zostały zdobyte (źródła wtórne), bądź można je zdobyć korzystając ze źródeł pierwotnych. Zaliczamy do nich $\mathrm{m}$. in. ankiety, wywiady, techniki projekcyjne, obserwacje, metody heurystyczne, eksperymenty. Ankieta jest metodą, która polega na dostarczeniu respondentowi zestawu pytań w postaci kwestionariusza ankietowego, na które respondent wypowiada się w sposób pisemny. Rozróżniamy ankiety takie jak: rozdawane, ogólne, pocztowe, internetowe, opakowaniowe, audytoryjne, radiowe i telewizyjne.

Miasto Mielec jest położone w południowo-wschodniej części Polski, w województwie podkarpackim. Miasto Mielec zaopatrywane jest w wodę za

\footnotetext{
${ }^{1}$ Autor do korespondencji / corresponding author: Janusz R. Rak, Politechnika Rzeszowska, al. Powstańców Warszawy 6, 35-959 Rzeszów, tel. 17 865-14-49, rakjan@ prz.edu.pl

2 Anna Sobuś, Politechnika Rzeszowska
} 
pomocą ujęcia brzegowo-komorowego na rzece Wisłoka, o projektowanej wydajności $26500 \mathrm{~m}^{3} / \mathrm{d}$. Woda surowa jest pobierana na prawym brzegu rzeki Wisłoki. W miejscu ujęcia został utworzono próg piętrzący, którego zadaniem jest podnoszenie zwierciadła wody na wysokość $2,2 \mathrm{~m}$. Woda, która jest pobierana tłoczona zostaje rurociągiem o średnicy $800 \mathrm{~mm}$ i długości $1600 \mathrm{~m}$ do Stacji Uzdatniania Wody w Mielcu [3].

Przeprowadzony sondaż został utworzony, aby zbadać zadowolenie użytkowników wodociągu mieleckiego wynikające z jakości wody, jak i jej ilości, utrudnień spowodowanych przerwami w jej dostawie oraz zadowolenia z jakości usług świadczonych przez przedsiębiorstwo wodociągowe wśród jego mieszkańców, szczególnie przez Biuro Obsługi Klienta.

\section{Materiał i metody}

Na potrzeby pracy zostały przeprowadzone badania wśród mieszkańców miasta Mielca, korzystających z wodociągu mieleckiego. Znalazły się także osoby korzystające nie tylko z usług miejscowej firmy wodociągowej ale także, korzystające dodatkowo z własnego źródła jakim jest studnia. Badania przeprowadzono osobiście wśród mieszkańców bloków, domów jednorodzinnych oraz kamienic.

Formularze ankiety zostały rozdane wśród losowo wybranych osób zamieszkujących obszar, na którym przeprowadzano badania, a zatem możliwość przedstawienia swojej opinii dotyczącej badanych cech miały zarówno osoby, zwracające na co dzień uwagę na badane parametry jak i te, u których refleksja nad nimi pojawiła się dopiero w trakcie wypełniania formularza.

Ankieta składała się z 30 pytań, w tym 4 z nich były pytaniami metryczkowymi, natomiast pozostałe 26 - pytaniami merytorycznymi. Wśród nich wyróżnić można pytania zamknięte jednokrotnego, bądź wielokrotnego wyboru, których było 26 . Pytania w metryczce dotyczyły płci, wieku, wykształcenia oraz miejsca zamieszkania respondentów. W kwestionariuszu znalazły się również pytania filtrujące, sprawdzające czy respondent korzysta $\mathrm{z}$ wody wodociągu mieleckiego. Jeśli odpowiedź była negatywna to ankieta była odrzucana z puli zebranych do analizy.

W badaniu wzięły udział zarówno kobiety, jak i mężczyźni. Przeprowadzono 100 ankiet. W tym 55 uczestników badania to kobiety, a 45 mężczyźni. Największą częścią osób badanych była grupa poniżej 25 roku życia oraz grupa 41-65, procentowy ich udział w badaniu wynosił kolejno 36\% i 32\%. Najmniejszą populację stanowiła grupa powyżej 65 lat, której procentowy udział w ankiecie wynosił $8 \%$. Biorąc pod uwagę płeć osób ankietowanych można zauważyć, że w przedziale <25 oraz 41-65 więcej było kobiet, natomiast w pozostałych dwóch przedziałach przeważali mężczyźni.

Wśród osób badanych były osoby o różnym poziomie wykształcenia. Ankietę wypełniły osoby zarówno z wykształceniem średnim jak i wyższym, zawo- 
dowym czy podstawowym. W badaniu przeważały osoby $\mathrm{z}$ wykształceniem średnim (56\%). Najmniejszymi grupami były osoby z wykształceniem podstawowym $12 \%$ oraz zawodowym $10 \%$. Wykształcenie wyższe zdeklarowało $22 \%$ osób badanych. większość respondentów mieszka w domach jednorodzinnych i blokach, to jest kolejno 52\% i $42 \%$ wszystkich ankietowanych. Najmniejszą grupę stanowią osoby mieszkające w kamienicach $(6 \%)$.

\section{Dyskusja otrzymanych wyników}

\subsection{Znajomość systemu zaopatrzenia w wodę miasta Mielca}

W kwestionariuszu znalazły się pytania o zasoby wód z jakich korzysta wodociąg oraz cenę $1 \mathrm{~m}^{3}$ wody. $\mathrm{Z}$ przeanalizowanych danych wynika, że tylko niewiele ponad połowa ankietowanych, bo 55\% wie z jakich zasobów korzysta wodociąg. Znajomość taką zdeklarowało 58\% kobiet biorących udział w badaniu oraz $51 \%$ mężczyzn. Kolejne pytanie w ankiecie było bardziej szczegółowe i skierowane do osób, które na poprzednie pytanie odpowiedziały twierdząco. Wymagało od respondentów konkretnej wiedzy. Źródłem wody w wodociągu mieleckim jest rzeka Wisłoka.

Znaczna większość osób twierdzących, że zna zasoby wodociągu mieleckiego dobrze odpowiedziało na pytanie jakie to zasoby, było to $81,80 \%$ (45 osób). Natomiast $14,60 \%$ (8 osób) ankietowanych zaznaczyło odpowiedź: wody podziemne, a 3,60\%(2 osoby) wody powierzchniowe stojące. Znajomość zasobów wody wodociągu mieleckiego przez respondentów przedstawiono na rysunku 1.

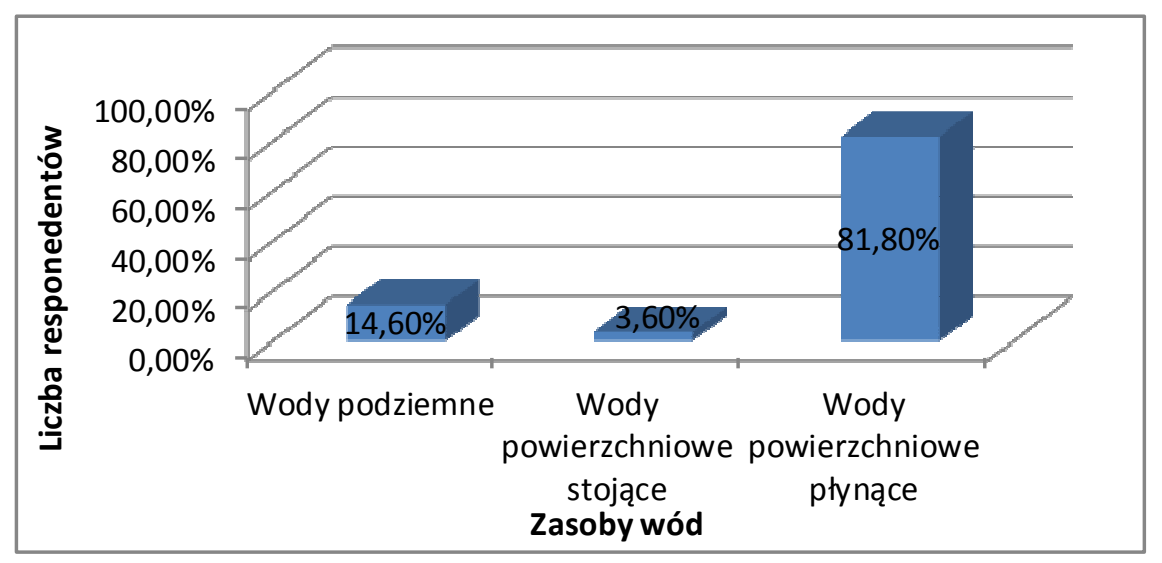

Rys. 1. Wykres przedstawiający znajomość zasobów wód z jakich korzysta wodociąg mielecki

Fig. 1. Graph showing knowledge of water resources in water supply system in Mielec 
Kolejne pytanie dotyczyło ceny $1 \mathrm{~m}^{3}$ wody. Pośród ankietowanych $59 \%$ deklaruje znajomość ceny wody. W celu sprawdzenia wiedzy respondentów zadano pytanie szczegółowe o podanie konkretnej ceny. Cena $1 \mathrm{~m}^{3}$ wody wodociągowej bez opłaty kanalizacyjnej podczas badania wynosiła 3,51 zł. Tylko $39 \%$ (23 osoby) ankietowanych poprawnie określiła cenę wody. Aż 33,90\% (20 osób) badanych osób wskazało cenę niższą niż faktyczna, natomiast 27,10\% (14 osób) ankietowanych wskazało cenę wyższą od rzeczywistej. Uzyskane dane przedstawiono na rys. 2.

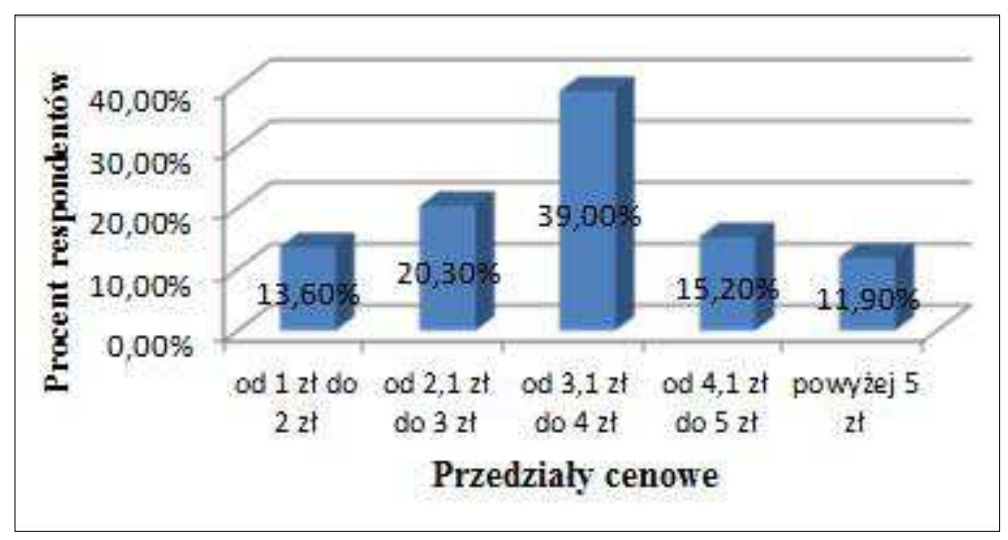

Rys. 2. Ceny $1 \mathrm{~m}^{3}$ wody według osób deklarujących jej znajomość

Fig. 2. Prices of $1 \mathrm{~m}^{3}$ of water by people declaring such knowledge

\subsection{Ocena jakości wody}

Jednym z najważniejszych czynników, które wpływają na zadowolenie użytkowników wody wodociągowej jest jej jakość. Na rysunku 3 przedstawiono ocenę jakości wody w skali 1-5 przez użytkowników wodociągu mieleckiego.

$\mathrm{Z}$ podanych wyżej danych wynika, że większość respondentów $47 \%$ (oceny 4 i 5) pozytywnie ocenia jakość wody wodociągu mieleckiego. Niezadowolenie z jakości wody, czyli oceny 1-2 wyraziło $12 \%$ ankietowanych. Znaczna część ankietowanych $41 \%$, określiła jakość wody na ocenę 3 co uznać można za jakość przeciętną. Po przeanalizowaniu oceny wody wśród respondentów pod względem płci można stwierdzić, że są one bardzo podobne. 


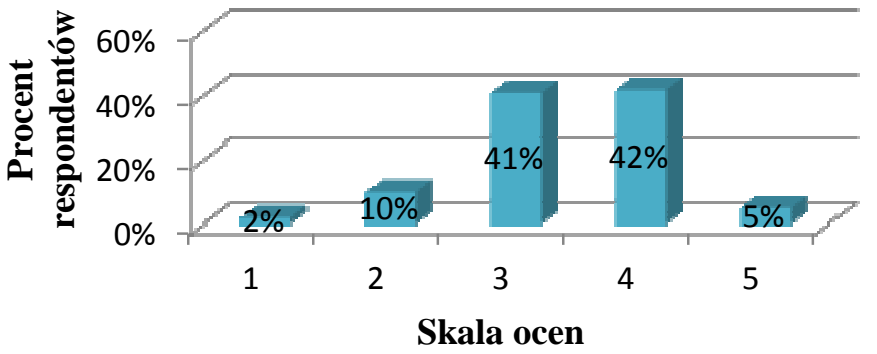

Rys. 3. Ocena jakości wody przez ankietowanych w skali 1-5

Fig. 3. The assessment of water quality by the respondents on a scale 1-5

Oceniając wodę wodociągową należy wziąć pod uwagę też jej właściwości chemiczne, fizyczne i organoleptyczne. Osobom biorącym udział w badaniu zostały zdane pytania na temat smaku, zapachu, klarowności i walorów zdrowotnych wody. Respondenci mieli do dyspozycji pięciostopniową skale. W pytaniach dotyczących smaku i zapachu większość osób oceniła te parametry jako dobre. Jeśli chodzi o klarowność i walory zdrowotne większość respondentów nie miała określonego zdania na ten temat. Szczegółowe zestawienie pokazano na rysunku 4.

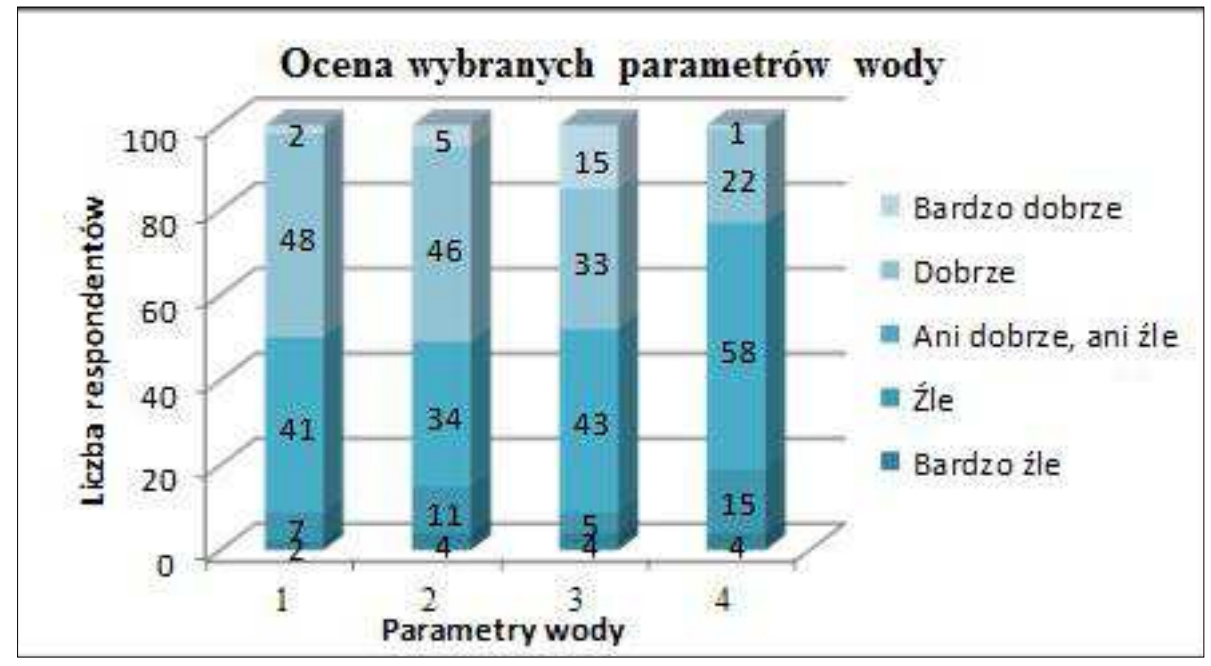

Rys. 4. Zestawienie ocen wybranych parametrów wody

Fig. 4. Summary ratings of selected water parameters 
Podsumowując najwięcej osób, które wzięło udział w badaniu było zadowolonych z zapachu i smaku wody wodociągowej, to jest kolejno 51 i 50 osób. $\mathrm{Z}$ analizy zebranych danych wynika, że bardziej zdecydowani $\mathrm{w}$ ocenie byli mężczyźni, gdyż w porównaniu z kobietami zaznaczyli oni więcej ocen negatywnych oraz pozytywnych. Znaczna część kobiet przy ocenie większości parametrów nie miała zdania. Ponad połowa mężczyzn biorących udział w badaniu jest zadowolona ze smaku, zapachu i klarowności wody. Jeśli zaś chodzi o kobiety to zadowolonych jest około $40 \%$ ze wszystkich parametrów o jakie pytanie w kwestionariuszu.

\subsection{Opinia respondentów na temat działania firmy wodociągowej}

Kolejna seria pytań dotyczyła opinii badanych osób na temat obsługującej ich firmy wodociągowej. Pierwsze pytanie z tej tematyki dotyczyło jakości usług świadczonych przez firmę. Dane te przedstawiono na rysunku 5.

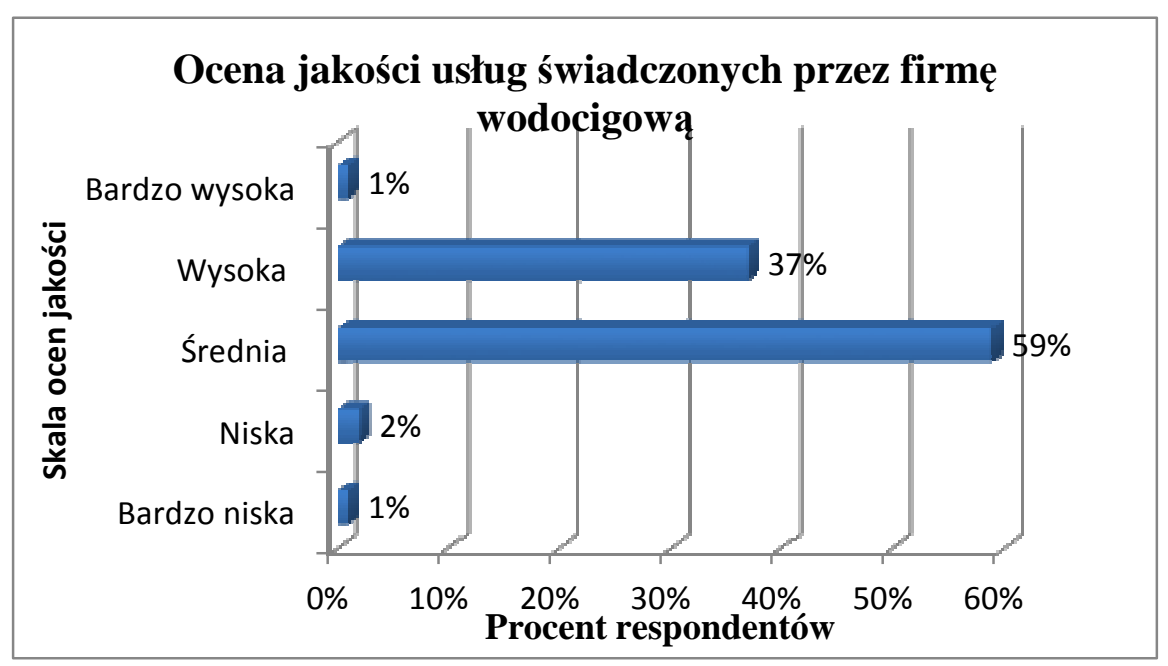

Rys. 5. Dane dotyczące opinii respondentów na temat jakości usług świadczonych przez firmę wodociągową

Fig. 5. The data on respondents' opinions on the quality of services provided by water supply

Prawie 3/5 badanych osób, czyli 59\% określiło jakość usług świadczonych przez firmę wodociągową jako średnią. Duża część z nich jest zadowolona z usług firmy o czym świadczy fakt, iż 37 osób zaznaczyło odpowiedź wysoka, a jedna osoba odpowiedź bardzo wysoka. Niezadowolenie okazuję się być niewielkie, gdyż odpowiedzi niska lub bardzo niska zaznaczyło 3 osoby.

Następne pytanie dotyczyło otrzymywanych rachunków za zużywaną wodę wodociągową. Dla większości respondentów rachunki są czytelne i zrozumiałe, 
taka odpowiedź zaznaczyło 57 ankietowanych. Niewielka liczba osób badanych nie rozumie i nie umie odczytać rachunków, 6 osób.

Kolejne pytanie dotyczyło Biura Obsługi Klienta firmy wodociągowej. Po zestawieniu wyników badań, stwierdzono, że $41 \%$ respondentów miało kontakt z Biurem Obsługi Klienta, a 59\% badanych nie miało z nimi styczności. Osobom, które miały kontakt z Biurem Obsługi Klienta zadano pytanie na temat pracy jego pracowników. Większość z badanych osób wskazywała na pozytywne cechy, jednak znalazło się kilka osób, które ocenił prace biura negatywnie. Przez największą część osób, które miały kontakt z Biurem Obsługi Klienta, pracownicy byli określani jako kompetentni $(73,20 \%)$ i uprzejmi $(61 \%)$. Jeśli zaś chodzi o oceny negatywne to najczęściej pojawiła się opinia o powolności obsługi. Respondenci zostali zapytani także o preferowany kontakt z firmą wodociągową. Po przeanalizowaniu uzyskanych danych okazało się, że znaczna większość badanych osób preferuje kontakt telefoniczny z firmą wodociągową, to jest $55,30 \%$ respondentów.

\subsection{Analiza opinii na temat przerw $w$ dostawie wody}

Istotnym czynnikiem wpływającym na ocenę jakości firmy wodociągowej jest częstość przerw w dostawie wody oraz sposób i skuteczność powiadamiania o nich. Pierwsze pytanie z tej części dotyczyło uciążliwości przerw w dostawie wody w zależności od długości ich trwania.

Z przeanalizowanych opinii na temat uciążliwości wody wynika, że wraz ze zwiększaniem się częstości w dostawie wody, zwiększała się uciążliwość odczuwana przez respondentów. Brak wody do 6 godzin w ciągu roku jest najmniej uciążliwy według ankietowanych, nie przeszkadza on $71 \%$ badanych osób. Podobnie kształtuje się opinia na temat przerw w przedziale 7-12 godzin w ciągu roku, gdzie brak dostawy wody nie przeszkadzałby $68 \%$ respondentów. W tych dwóch przedziałach brak wody bardzo przeszkadzałby niewielkiej liczbie badanych osób, to jest kolejno 6\% i 11\%. W przedziale od 13 do 24 godzin bez wody w ciągu roku można zauważyć, że tylko dla $38 \%$ respondentów brak wody nie byłby problemem. Analizując kolejne przedziały można zauważyć, że bark dostawy wody przeszkadzałby już większości badanych osób.

Znaczna większość (77\%) respondentów uważa, że awarie sieci wodociągowej są najczęstszą przyczyną braku dostaw wody. Kolejno $26 \%$ badanych osób jest zdania, że przyczyną tego zjawiska jest przestarzały proces uzdatniania wody. Najmniejsza część respondentów uważa, że brak wody spowodowany jest błędami projektowymi lub wykonawczymi.

Respondenci zostali zapytani również o to jakie straty, bądź nieudogodnienia powoduje brak dostaw wody. Mając do wybory kilka odpowiedzi ankietowani mogli zaznaczyć kilka z nich. Największa część z nich stwierdziła, że największym nieudogodnieniem byłaby przerwa w dostawie wody uniemożliwiająca dbanie o higienę osobistą, takiej odpowiedzi udzieliło $81 \%$ badanych osób. Wyniki pokazano na rysunku 6. 


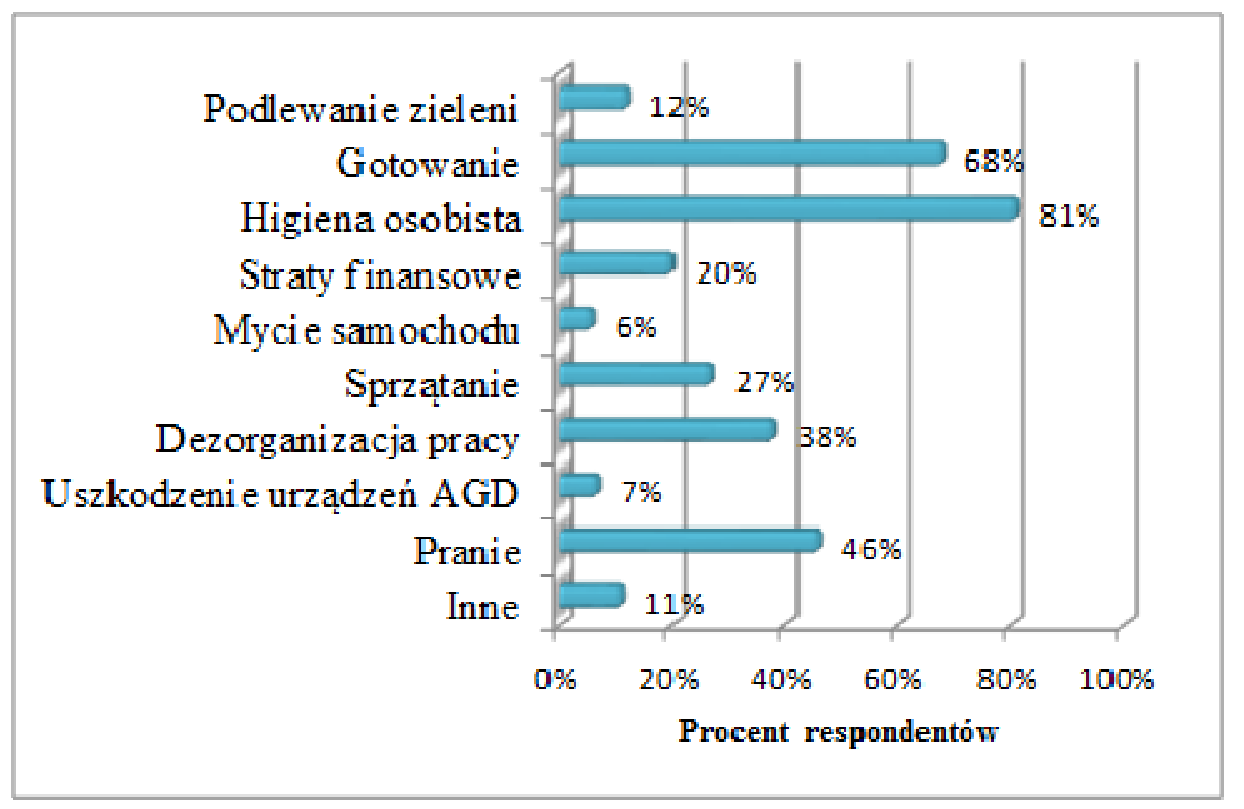

Rys. 6. Opinia respondentów na temat strat i nieudogodnień spowodowanych przerwami w dostawie wody

Fig. 6. The opinion of the respondents about the loss and inconvenience caused by interruptions of water supply

Analizując pytanie o starty i nieudogodnienia powodowane przez przerwy w dostawie wody można stwierdzić, że są występują one w różnych sferach życia. Najbardziej uciążliwe okazały się przerwy w dostawie wody jeśli chodzi o: gotowanie $68 \%$, higiena osobista $81 \%$ czy pranie $46 \%$. Straty finansowe odczuwa $20 \%$ respondentów. Porównując odpowiedzi respondentów pod względem zamieszkania, można dostrzec różnicę. Jeśli chodzi o mycie samochodu to wszystkie odpowiedzi były zaznaczone przez mieszkańców domów jednorodzinnych. Podobnie jest w przypadku podlewania zieleni, gdzie na 12 uzyskanych odpowiedzi 10 udzieliły osoby mieszkające w domach jednorodzinnych. Jeśli chodzi o mieszkańców bloków i kamienic, to większość z odpowiedzi był zaznaczona przez nich. Odpowiedzi na pozostałe pytania kształtowały się równomiernie między mieszkańcami domów jednorodzinnych, a mieszkańcami bloków i kamienic.

Kolejnym czynnikiem wpływającym na jakość usług świadczonych przez firmę wodociągową jest skuteczność powiadamiania o brakach dostawy wody. Dlatego respondenci zostali poproszeni o odpowiedź na pytanie dotyczące skuteczności sposobu powiadamiania o przerwach w dostawie wody. Z przeanalizowanych danych wynika, że $48 \%$ respondentów jest zadowolonych (ocena dobra $46 \%$ i bardzo dobra $2 \%$ ) z istniejącego sposobu powiadamiania o przerwach 
w dostawie wody. Duża część badanych osób nie ma zdania na ten temat co można wywnioskować z tego, że aż 39\% z nich zaznaczyło odpowiedź ,,ani dobry, ani zły". Spośród wszystkich respondentów 13\% jest niezadowolonych $\mathrm{z}$ dotychczasowego sposobu powiadamiania o przerwach w dostawie wody wodociągowej. Ocena negatywna może być spowodowana niedocieraniem informacji dotyczących przerw w dostawie wody wodociągowej do mieszkańców, dlatego respondentów zapytano o sposób dowiadywania się o przerwach w dostawie wody. Z odpowiedzi ankietowanych wynika, że najwięcej osób $(81 \%)$ takie informacje uzyskuje z ogłoszeń. Grupa do której nie docierają informacje o braku wody, to zaledwie $4 \%$ ankietowanych.

\section{Podsumowanie i wnioski}

Przedmiotem badań sondażowych była opinia użytkowników wodociągów miasta Mielec na temat funkcjonowania wodociągów, która umożliwiła ogólną ocenę jakości wody oraz warunków jej dostawy. Przeprowadzone badania pozwoliły określić przypuszczalnie jaką opinię na temat jakości Biura Obsługi Klienta oraz uciążliwości wynikających z przerw w dostawie wody wodociągowej mają mieszkańcy Mielca.

Analizując wyniki badań na temat jakości wody można stwierdzić, że większość ankietowanych jest zadowolonych. Jeśli chodzi o parametry wody wodociągowej to najlepiej zostały ocenione jej smak i zapach. Większość z badanych osób jest zadowolona z prowadzenia Biura Obsługi Klienta. Z przeprowadzonego sondażu wynika, że znaczna część osób ankietowanych nie wie z jakich zasobów korzysta wodociąg mielecki czy ile kosztuje $1 \mathrm{~m}^{3}$ wody wodociągowej.

Firma wodociągowa, aby podnosić jakość swoich usług powinna przeprowadzać okresowe badania opinii społecznej. Dzięki temu będzie w stanie zwiększyć zadowolenie oraz satysfakcję użytkowników [4, 9, 13].

Przeprowadzone badania wśród użytkowników wodociągu mieleckiego pozwalają na wyciągnięcie następujących wniosków:

- Badania wykazały, że tylko 55\% ankietowanych deklaruje znajomość zasobów wodnych wodociągu. $\mathrm{Z}$ tego $81,80 \%$ poprawnie określiło jakie to zasoby.

- Ceny za $1 \mathrm{~m}^{3}$ wody nie zna $41 \%$ badanych osób. Pośród deklarujących znajomość ceny tylko $39 \%$ poprawnie ją określiła.

- Z jakości wody jest zadowolonych $47 \%$ użytkowników wodociągu mieleckiego. Dla dużej liczby ankietowanych (41\%) jest on przeciętna. Oceny jakości wody kształtowały się podobnie w przypadku obydwu płci.

- Ocena parametrów wody wodociągowej pozwala zauważyć, że zadowolonych ze smaku i zapachu jest około połowa badanych osób, to jest kolejno 50 i 51\%. Niezadowolenie zdeklarował niewielki procent osób biorących udział w badaniu. Jeśli chodzi o klarowność wody i jej walory zdrowotne większość respondentów nie potrafiła odpowiedzieć, czy są one dobre czy złe. 
- Prawie 3/5 badanych osób, czyli 59\% określiło jakość usług firmy wodociągowej jako średnią.

- Z przeprowadzonego sondażu wynika, że ankietowani są zadowoleni z pracy Biura Obsługi Klienta. Respondenci oceniając pracę pracowników Biura Obsług Klienta w większość wskazywali na pozytywne cechy: kompetentna $(73,20 \%)$ oraz uprzejma (61\%). Ponad połowa ankietowanych deklarowała, że preferuje telefoniczny kontakt z firmą wodociągową.

- Poziom uciążliwości przerw w dostawie wody wśród ankietowanych rósł wraz z długością tych przerw w czasie. Najmniej przeszkadzającymi są przerwy do $12 \mathrm{~h}$ w ciągu roku. Natomiast bardzo przeszkadzają przerwy trwające powyżej 1 doby.

- Najwięcej badanych osób (77\%) uważa, że przerwy w dostawie wody spowodowane są przez awarie sieci wodociągowej.

- Najbardziej odczuwalny brak wody dla respondentów jest spowodowany nieudogodnieniami, jeśli chodzi o higienę osobistą i gotowanie.

- Około 3/4 ankietowanych (71\%) podczas przerw w dostawie wody korzysta z zakupionej wody mineralnej.

- Znaczna część ankietowanych (55\%) nie wie jakie jest przeciętne miesięczne zużycie wody na jednego mieszkańca. Z osób deklarujących znajomość zużycia wody tylko 57,80\% potrafiło ją prawidłowo określić.

\section{Literatura}

[1] Badania marketingowe. Podstawowe metody i obszary zastosowań, pod red. K. Mazurek-Łopocińskiej, Wydawnictwo Akademii Ekonomicznej we Wrocławiu, Wrocław 1996.

[2] Churchill G. A., Badania marketingowe. Podstawy metodologiczne, Wydawnictwo Naukowe PWN, Warszawa 2002.

[3] Kowalczyk A., Mielec, w: Nowicki Z. (red.), Informator Państwowej Służby Hydrogeologicznej. Wody podziemne miast Polski. Miasta powyżej 50000 mieszkańców. Państwowy Instytut Geologiczny, Warszawa 2009, s. 219-235.

[4] Pietrucha-Urbanik K., Badanie opinii użytkowników wodociągów publicznych na temat przerw w dostawie wody, Międzynarodowa Konferencja Naukowo-techniczna, Przedsiębiorstwa wodociągowo-kanalizacyjne w dobie współczesnych problemów, 2009, s. 71-84

[5] Pietrucha-Urbanik K., Bernacka A.: Analysis of Water Infrastructure Development a Case Study of the Exemplary Water Supply System. Czasopismo Inżynierii Lądowej, Środowiska i Architektury - Journal of Civil Engineering, Environment and Architecture, JCEEA, z. 63 (3/2016), s. 221-230. DOI: 10.7862/rb.2016.124.

[6] Rak J.: Metoda planowania remontów sieci wodociągowej na przykładzie miasta Krosna. Czasopismo Inżynierii Lądowej, Środowiska i Architektury - Journal of Civil Engineering, Environment and Architecture, JCEEA, z. 61 (1/14), 2014, s. 225232. DOI:10.7862/rb.2014.15. 
[7] Rak J.R.: Propozycja oceny dywersyfikacji objętości wody w sieciowych zbiornikach wodociągowych, Czasopismo Inżynierii Lądowej, Środowiska i Architektury - Journal of Civil Engineering, Environment and Architecture, JCEEA, t. XXXII, z. 62 (1/15), 2015, s. 339-349. DOI:10.7862/rb.2015.23.

[8] Rak J., Zasady badań marketingowych związanych z zaopatrzeniem w wodę, Wodociągi - Kanalizacja, 5(14)2005, Wydawnictwo Abrys, Poznań, s. 13-16.

[9] Rak J., Pietrucha-Urbanik K., Badanie sondażowe związane z brakiem dostawy wody wodociągowej w sytuacjach kryzysowych, Instal 2/2016, s. 54-58.

[10]Rak, J., Pietrucha-Urbanik, K. New directions for the protection and evolution of water supply systems - smart water supply. Czasopismo Inżynierii Lądowej, Środowiska i Architektury - Journal of Civil Engineering, Environment And Architecture. JCEEA, z. 62 (3/I/2015), pp. 365-373. DOI: 10.7862/rb.2015.121.

[11]Rak J., Tułacz E., Analiza opinii sondażu użytkowników wodociągów temat przerw w dostawie wody, Zeszyty Naukowe Politechniki Rzeszowskiej Budownictwo i Inżynieria Środowiska, z.37/2004, s. 337-348.

[12]Rak J., Tchórzewska-Cieślak B., Studziński A., Pietrucha-Urbanik K., Boryczko K., Niezawodność i bezpieczeństwo systemów zbiorowego zaopatrzenia w wodę, Oficyna Wydawnicza Politechniki Rzeszowskiej, Rzeszów 2012.

[13] Wieczysty A., Krawczyk P., Ocena uciążliwości przerw w dostawie wody przez jej odbiorców [w:] Materiały II Ogólnopolskiej Konferencji N-T „Bezpieczeństwo, niezawodność, diagnostyka urządzeń i systemów gazowych, wodociągowych, kanalizacyjnych, grzewczych", Wydawnictwo PZITS O/Kraków nr 797/2001, Zakopane, s. 409-417.

\section{ANALYSIS OF CONSUMERS OPINION OF WATER FROM THE MIELEC WATER SUPPLY SYSTEM}

\section{S u m m a r y}

The analysis of the opinions are the most important component letting correct the functioning of the system the water supply and the safety of his functioning. In the thesis result of resarch about satisfaction from functioning of public water supply systems by consumers using their services. The resarch was performer by 100 respondents from the city of Mielec. The resarch included opinions of respondents about prices and the quality of water, nonconveniences and the level for the nuisance from services were included.

Keywords: questionnaire, water supply system, water supply interruption

Przestano do redakcji: 22.02 .2017 r.

Przyjęto do druku: 31.03.2017 r. 